\title{
Manajemen Kebutuhan Ruang Parkir Kampus (Studi Kasus: Fakultas Sains dan Teknologi UIN Suska Riau)
}

\author{
Syaifullah $^{1}$, Hasdi Radiles ${ }^{2}$, Tengku Khairil Ahsyar ${ }^{3}$ \\ ${ }^{1,3}$ Program Studi Sistem Informasi, Fakultas Sains dan Teknologi, UIN Sultan Syarif Kasim Riau \\ Jl. HR. Soebrantas No. 155 Simpang Baru, Panam, Pekanbaru, 28293 \\ Email: syaifullah@uin-suska.ac.id, tengkukhairil@uin-suska.ac.id \\ ${ }^{2}$ Program Studi Teknik Elektro, Fakultas Sains dan Teknologi, UIN Sultan Syarif Kasim \\ Jl. HR. Soebrantas No. 155 Simpang Baru, Panam, Pekanbaru, 28293 \\ Email: hasdiradiles@uin-suska.ac.id
}

\begin{abstract}
ABSTRAK
Universitas Islam Negeri Sultan Syarif Kasim Riau merupakan pusat aktivitas perkuliahan sarjana (Strata 1) yang memiliki visi dan misi menjadi World Class University di tahun 2023. Salah satu fakultas favorit yakni Fakultas Sains dan Teknologi yang telah mengalami perkembangan yang cukup signifikan. Tingginya peningkatan populasi mahasiswa dari tahun ke tahun menjadi isu penting untuk melakukan investigasi tentang kesiapan prasarana parkir di lingkungan FST. Tujuan penelitian ini untuk mengetahui manfaat metode Satuan Ruang Parkir dalam mengatasi permasalahan parkir di lingkungan FST dengan memodifikasi parameter populasi civitas akademika dalam memperkirakan kebutuhan parkir maksimum. Hasil penelitian ini adalah dengan memanfaatkan lahan area terbuka disekitar kampus hanya mampu memberikan pelayanan kepada 948 sepeda motor atau sekitar 75\% dari kebutuhan SRP sepeda motor. Solusi untuk membangun gedung parkir ataupun dengan melakukan kebijakan parkir sangat dibutuhkan dalam mengatasi permasalahan parkir di lingkungan FST.
\end{abstract}

Kata Kunci: Fakultas Sains dan Teknologi, Kampus, Parkir, Satuan Ruang Parkir

\section{ABSTRACT}

State Islamic University Sultan Syarif Kasim Riau is a center of undergraduate academic activities that has a vision and mission to become World Class University in 2023. One of the favorite faculty, the Faculty of Science and Technology has experienced significant growth. The high increase of student population from year to year. Thus, it is necessary to conduct an investigation of the pre-parking readiness in the FST environment. The purpose of this research is to know the benefit of SRP method in overcoming parking problem in FST environment by modifying population parameter of academic community in estimating maximum parking requirement. The result of this research is by utilizing open area around campus only able to give service to 948 motorbike or about $75 \%$ from requirement of SRP motorcycle. The solution to build a parking building or by conducting a parking policy is needed in overcoming parking problems in the FST environment.

Keywords: Faculty of Science and Technology, Campus, Parking, Parking Space Unit

\section{Pendahuluan}

Universitas Islam Negeri Sultan Syarif Kasim (UIN Suska Riau) merupakan salah satu universitas negeri yang sedang berkembang dan dibangun di atas tanah seluas $974.934 \mathrm{~m}^{2}$. Seiring dengan visi dan misi UIN Suska Riau untuk menjadi World Class University (WCU) ditahun 2023, salah satu fakultas favorit yakni Fakultas Sains dan Teknologi (FST) telah mengalami perkembangan yang cukup signifikan. Hal ini dapat dilihat dari tingkat pertumbuhan civitas akademika yang cukup tinggi, terutama jumlah populasi mahasiswanya. Oleh karena itu, peningkatan kapasitas dan kualitas dari sarana dan prasarananya harus dapat mengimbangi laju pertumbuhan ini agar kenyamanan kegiatan civitas akademika dapat dipertahankan.
Isu penting yang berkaitan dengan peningkatan populasi dan kesiapan prasarana kampus adalah kebutuhan layanan parkir. Tingginya populasi ini ternyata telah memicu kondisi parkir menjadi semakin semrawut dan tidak terkendali [1], [2]. Kekurangan tempat parkir yang memadai memaksa mahasiswa menggunakan lahan parkir yang bukan pada tempatnya atau bahkan menggunakan lahan parkir yang diperuntukan khusus bagi pegawai/dosen. Kondisi parkir di lingkungan FST saat ini bukan hanya memperburuk keadaan dan kenyamanan civitas akademikanya, tetapi juga sudah mulai mengarah kepada maraknya berbagai tindakan kejahatan. Dengan kata lain, jika kondisi ini dibiarkan terus menerus, keinginan kampus untuk menjadi WCU, tentu harus dipertanyakan kembali. 
Penelitian terkait masalah kampus adalah seperti [1], [2], [3], [4], dan [5]. Umumnya pemodelan dilakukan dengan menggunakan metoda SRP [6]. Pemodelan kebutuhan ruang parkir kampus dilakukan berdasarkan hasil survei untuk kemudian diaplikasikan menggunakan metoda regresi linear [7]. Permasalahan manajemen dalam penelitian ini disebabkan oleh kurangnya tanda pentunjuk parkir dan garis marka. Dalam penelitian lainnya [8], metode analisa RCA telah sukses digunakan untuk memecahkan permasalahan manajemen. Dalam penelitian [3], kebutuhan ruang parkir dipengaruhi oleh minat mahasiswa dalam memilih jenis kendaraannya. Sedangkan prediksi kebutuhan ruang parkir untuk masa depan dihitung berdasarkan tingkat pertumbuhan populasi mahasiswa [2]. Di sini, populasi didefinisikan sebagai jumlah mahasiswa total yang terdaftar dengan mengabaikan faktor kemungkinan kehadirannya di kampus. Sehingga, hasil perhitungannya akan menjadi bias dengan tingkat kesalahan yang tinggi.

Oleh karena itu, sangat perlu untuk melakukan investigasi tentang kesiapan prasarana parkir di lingkungan FST terhadap tingginya peningkatan populasi mahasiswanya dari tahun ke tahun. Peneliti berpendapat bahwa semwrautnya parkir untuk mahasiswa ini disebabkan oleh kurangnya fasilitas parkir yang nyaman dan aman yang disediakan oleh pihak manajemen kampus. Sehingga, dengan memperhatikan lahan-lahan yang memungkinkan untuk dikembangkan sebagai parkir yang nyaman dan aman, diharapkan jumlah kebutuhan parkir dapat diatasi. Penelitian ini menggunakan metode survei untuk mengumpulkan data akumulasi parkir dan mendapatkan hubungannya terhadap populasi mahasiswanya.

\section{Metode Penelitian}

\section{Rancangan Penelitian}

Penelitian ini merupakan gabungan dari penelitian kualitatif dan kuantitatif agar dapat memberikan gambaran yang lebih terukur mengenai permasalahan parkir di lingkungan kampus, khususnya pada FST. Penelitian kualitatif dirancang menggunakan metode FGD [9], [10] dengan masukan gambaran (foto-foto) tentang suasana parkir di lingkungan FST. Sedangkan penelitian kuantitatif dilakukan dengan menggunakan metoda survei keluar/masuk kendaraan ke area parkir yang diinvestigasi. Pemilihan dan pengukuran kandidat area parkir dilakukan secara subjektif mengingat kebutuhan yang mendesak untuk mengfungsikan area-area terbuka di sekitar fakultas.

\section{Lokasi dan Waktu Penelitian}

Penelitian ini dilaksanakan selama enam bulan dan dilakukan di wilayah FST yang terletak di dalam lingkungan kampus Panam UIN Suska Riau.
Definisi dari lingkungan FST dalam penelitian ini dibatasi pada wilayah parkir yang terdiri dari tiga gedung, yaitu Gedung Perkantoran FST, Gedung Baru, dan Gedung Laboratorium. Pemilihan wilayah ini dilakukan mengingat tingkat kesulitan dalam mengendalikan populasi mahasiswa akibat dari sifat sharing (saling berbagi) antara FST dengan Fakultas Tarbiyah. Lokasi pengambilan data survei dapat dilihat pada Gambar 1.

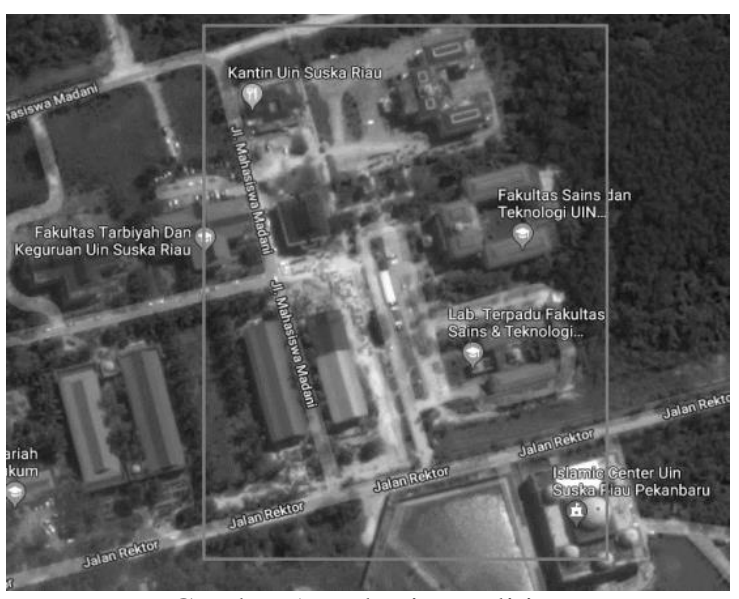

Gambar 1. Lokasi Penelitian

\section{Tahapan Penelitian}

Proses penelitian dibagi ke dalam tiga tahapan pelaksanaan, yakni tahap pendahuluan, pelaksanaan, dan pelaporan. Tahap pendahuluan dimulai sejak pengumuman dibukanya penelitian LPPM oleh panitia penyelenggara penelitian hingga batas waktu pengumpulan proposal. Pada tahap ini, kegiatan penelitian berlangsung cukup singkat dengan durasi pengerjaan sekitar 1 hingga 2 minggu. Proses yang terjadi pada tahap pendahuluan ini dilakukan secara iterasi untuk mendapatkan kualitas proposal yang berkualitas. Adapun tahapan-tahapan kegiatan pada proses penelitian pendahuluan dapat dilihat pada Gambar 2.

Kegiatan inti penelitian meliputi proses pengumpulan, pengolahan, analisa data, serta penarikan kesimpulan atau hasil penelitian. Tahapan ini dimulai sejak proposal dinyatakan lulus seleksi oleh panitia penyelenggara dan mendapatkan pencairan dana awal untuk membiayai semua kegiatan. Adapun Detail pelaksanaan ini diterangkan lebih jauh pada bagian bab terkait.

Tahapan selanjutnya adalah penulisan laporan dan persiapan persentasi akhir. Pada tahapan ini, seluruh kegiatan penelitian dituliskan secara sistematis, baik secara softcopy maupun hardcopy untuk kebutuhan presentasi dan dokumentasi. Kegiatan birokrasi dan administrasi yang terkait dengan penelitian juga merupakan bagian dari tahapan akhir ini. Sedangkan untuk melihat tahapan penelitian pelaksanaan, dapat dilihat pada Gambar 3 . 


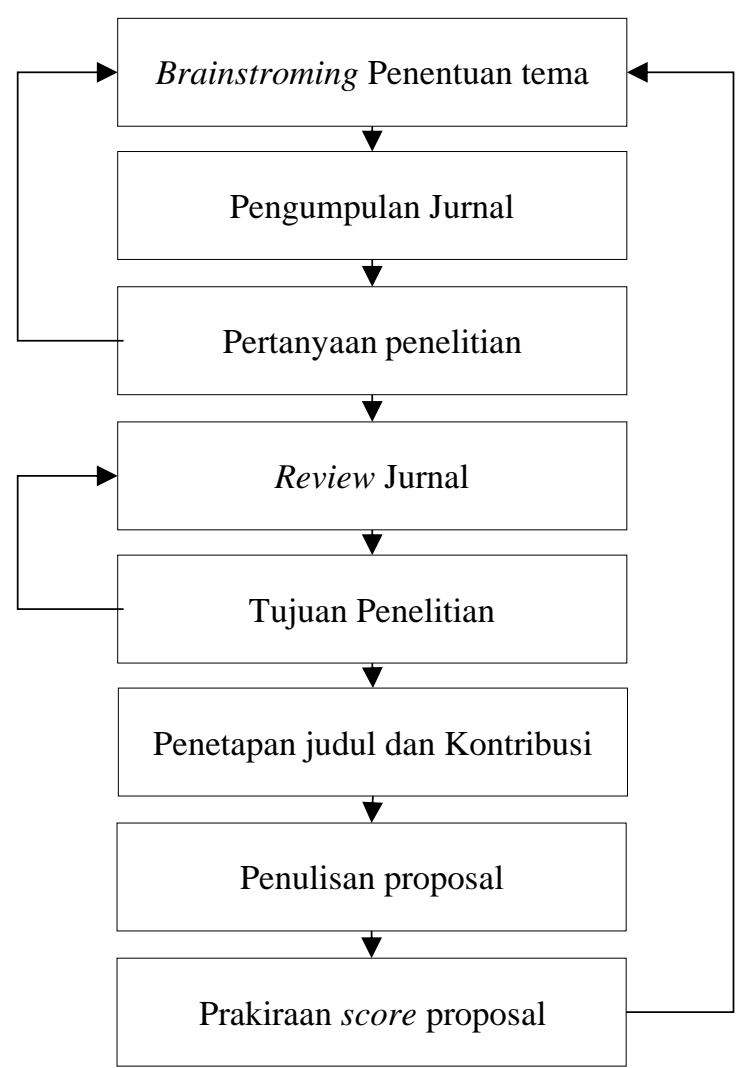

Gambar 2. Tahapan Penelitian Pendahuluan

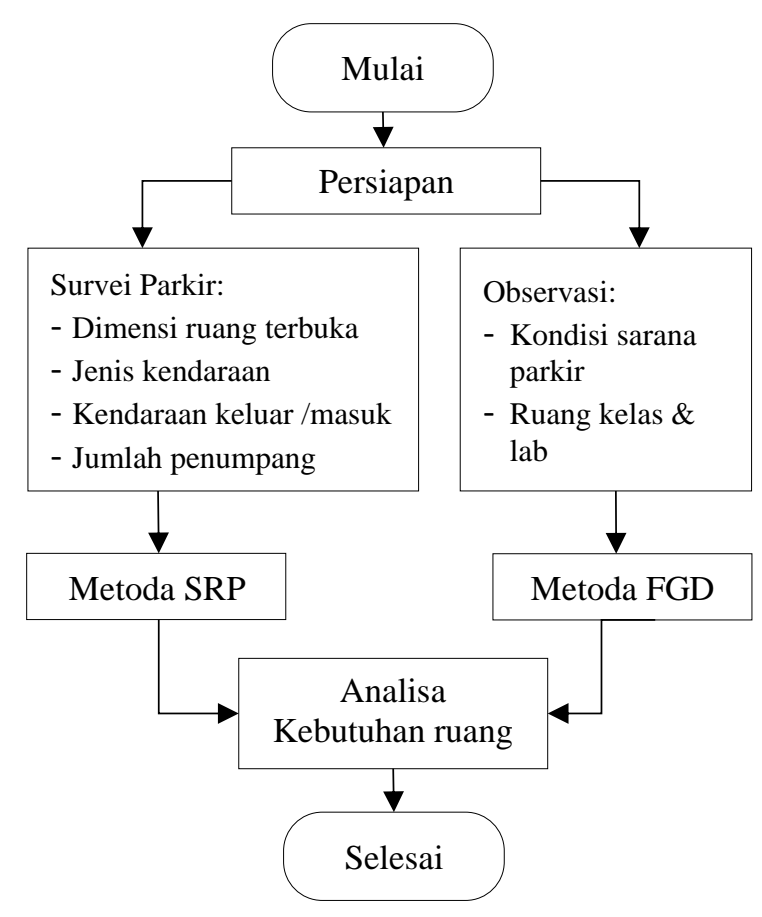

Gambar 3. Tahapan Penelitian Pelaksanaan

\section{Populasi dan Data Penelitian}

Definisi populasi dalam penelitian ini mencakup seluruh civitas akademika yang terkait dengan seluruh kegiatan kampus yang terjadi di lingkungan FST. Populasi ini meliputi himpunan mahasiswa, pegawai, dan dosen yang melakukan aktivitasnya diseluruh lingkungan kampus dalam durasi waktu tertentu. Dari populasi ini kemudian diamati jenis dan jumlah kendaraan yang keluar/masuk ke area parkir. Sehingga akumulasi parkir dalam selang waktu tertentu dapat diperkirakan lebih logis.

Jenis data yang diamati dapat digolongkan ke dalam dua katagori, yakni data primer dan data sekunder. Data primer meliputi data survei keluar/masuk kendaraan dan fenomena proses diskusi yang terjadi selama penyelenggaraan FGD (Focus Group Discussion) [9], [10], [11]. Sedangkan data sekunder berupa foto-foto pengamatan lokasi investigasi yang dikumpulkan secara observasi dan data-data lainnya yang menyangkut lingkungan kampus FST.

\section{Metode Pengumpulan Data}

Untuk mendapatkan data primer, sejumlah perangkat kerja yang perlu dipersiapkan berupa alat tulis dan kertas yang telah diformat ke dalam bentuk tabel-tabel yang diisi para surveyor sesuai dengan kebutuhan klasifikasi data yang diperlukan. Sedangkan untuk mendapatkan data sekunder, menggunakan kamera yang dapat meliput suasana parkir. Data-data mengenai karakteristik lingkungan kampus seperti kapasitas ruang kelas dan laboratorium didapatkan dari hasil observasi langsung dan pengukuran lewat situs Google Map untuk mendapatkan dimensi karakteristik area parkir.

Untuk dapat mengamati dan melakukan pengukuran di lapangan, area disekitar lingkungan FST di bagi menjadi lima titik pos pengamatan yang meliputi Zona 1 (Halaman Gedung Baru FST), Zona 2 (Halaman parkir gedung FST dan Laboratorium), Zona 3 (Koridor akses Masjid UIN Suska Riau), Zona 4 (Ruang terbuka depan FST), serta Zona 5 (Ruang terbuka samping kiri Gedung Psikologi lama).

Masing-masing pos pengamatan diisi oleh dua orang surveyor yang menghitung jumlah kendaraan yang keluar/masuk ke zona parkir masing-masing untuk jenis kendaraan golongan 1 dan sepeda motor. Kegiatan ini dilakukan secara terus-menerus selama lima hari kerja yakni pada hari senin hingga jumat yang dimulai dari pukul 08:00 16:00 WIB. Jumlah kendaraan yang keluar/masuk ini kemudian direkap dalam durasi perjam dan dinyatakan dalam tabel yang telah disediakan sebagai instrumen penelitian. Selain itu surveyor juga harus mengamati jumlah penumpang untuk mobil dan sepeda motor untuk mendapatkan data tentang minat pemilihan kendaraan mahasiswa ke kampus. 
Untuk pengukuran luas area terbuka yang menjadi kandidat tempat parkir dilakukan secara online dengan mengakses dan memanfaatkan fasilitas yang diberikan oleh website www.google.co.id/maps dengan mengakases map pada lokasi yang dimaksud. Hal ini mengingat waktu, tenaga, dan dana penelitian yang sangat terbatas untuk melakukan langsung di lapangan. Sedangkan pengamatan kondisi parkir yang diinvestigasi dilakukan menggunakan kamera digital pada lokasi-lokasi yang dikunjungi.

\section{Metode Analalisa Data}

Metode analisa data dalam penelitian ini menggunakan dua metode yakni SRP dan FGD. Untuk metode SRP, ruang terbuka disekitar lingkungan kampus dapat dijadikan kandidat tempat parkir dengan menyesuaikan terhadap dimensi petak parkir yang optimal. Dengan melakukan substitusi informasi pada tabel, tabel dan persamaan pada dimensi panjang dan tinggi untuk sudut parkir $90^{\circ}$, maka model rancangan petak parkir untuk maksimum 50 kendaraan berjajar dapat disederhanakan seperti yang tertera pada Tabel 1 .

Tabel 1. Dimensi Panjang dan Tinggi Petak Parkir $90^{\circ}$ Untuk Mobil dan Sepeda Motor

\begin{tabular}{|c|c|c|c|c|}
\hline \multirow{2}{*}{ Model } & \multicolumn{2}{|c|}{ Mobil } & \multicolumn{2}{c|}{ Sepeda motor } \\
\cline { 2 - 5 } & $\begin{array}{c}\text { Tinggi } \\
(\mathrm{m})\end{array}$ & $\begin{array}{c}\text { Panjang } \\
(\mathrm{m})\end{array}$ & $\begin{array}{c}\text { Tinggi } \\
(\mathrm{m})\end{array}$ & $\begin{array}{c}\text { Panjang } \\
(\mathrm{m})\end{array}$ \\
\hline $\mathrm{A}$ & 11 & $n \times 2.3$ & 4.5 & $n \times 0.75$ \\
\hline $\mathrm{B}$ & 13 & $n \times 2.3$ & 6.6 & $n \times 0.75$ \\
\hline $\mathrm{C}$ & 22 & $n \times 2.3$ & 9 & $n \times 0.75$ \\
\hline $\mathrm{D}$ & 16 & $n \times 2.3$ & 6.5 & $n \times 0.75$ \\
\hline
\end{tabular}

Sedangkan jadwal kegiatan FGD dilakukan sebanyak tiga kali, yakni dua kali sebelum proses pengumpulan data dan satu kali sesudah proses analisa. Pelaksanaan FGD secara umum dilakukan dengan rancangan seperti pada Tabel 2.

Tabel 2. Rancangan Jadwal Kegiatan FGD

\begin{tabular}{|l|l|}
\hline Topik FGD & $\begin{array}{l}\text { Faktor-faktor penyebab buruknya } \\
\text { manajemen parkir ditinjau dari } \\
\text { manusia, ketersedian lahan, } \\
\text { kebijakan kampus dan peralatan } \\
\text { parkir yang digunakan. }\end{array}$ \\
\hline $\begin{array}{l}\text { Tujuan } \\
\text { Pelaksanaan }\end{array}$ & $\begin{array}{l}\text { Mendapatkan opini dari peserta } \\
\text { diskusi tentang manajemen kampus } \\
\text { dilingkungan FST }\end{array}$ \\
\hline $\begin{array}{l}\text { Target } \\
\text { undangan }\end{array}$ & $\begin{array}{l}\text { - Moderator/fasilitator } \\
\text { - Pencatat/notulen } \\
\text { - Tukang photo/kamera } \\
\text { - Peserta diskusi terdiri dari 10 orang } \\
\text { - Pengamat (peneliti) }\end{array}$ \\
\hline Tempat & $\begin{array}{l}\text { Ruang rapat/kelas yang tersedia di } \\
\text { FST }\end{array}$ \\
\hline $\begin{array}{l}\text { Perlengkapan } \\
\text { diskusi }\end{array}$ & Alat tulis meliputi: Kertas, \\
& \multicolumn{2}{|c|}{ pulpen, spidol, dan papan tulis } \\
\hline
\end{tabular}

\begin{tabular}{|c|c|}
\hline & $\begin{array}{l}\text { - Alat presentasi: Laptop, infocus, } \\
\text { sistem audio } \\
\text { - Alat rekam: Kamera, laptop } \\
\text { - } \quad \text { Bahan: Makalah, file gambar } \\
\text { tentang parkir } \\
\text { - Perabot: Kursi dan meja } \\
\text { - Konsumsi }\end{array}$ \\
\hline $\begin{array}{l}\text { Tertib acara } \\
\text { diskusi }\end{array}$ & $\begin{array}{l}\text { - } \text { Pembukaan oleh moderator } \\
\text { - } \\
\text { - kengantar kondisi manajemen di FST } \\
\text { - Pembahasan tentang faktor- } \\
\text { faktor manusia, lahan, kebijakan } \\
\text { dan peralatan yang digunakan, } \\
\text { dengan meminta opini dari } \\
\text { peserta diskusi } \\
\text { - Penyimpulan diskusi } \\
\text { - Penutup }\end{array}$ \\
\hline
\end{tabular}

\section{Hasil dan Pembahasan}

\section{Investigasi Kondisi Parkir di Lingkungan FST}

Meningkatkan kebutuhan parkir di lingkungan FST disebabkan oleh semakin besarnya populasi civitas akademika dari tahun ke tahun. Kurangnya perhatian dan antisipasi akan kebutuhan parkir, telah menyebabkan semwrautnya kondisi parkir di lingkungan FST. Minimnya pembangunan sarana parkir yang dilakukan pihak pengelola kampus juga memicu mahasiswa bertindak anarkis dengan memarkir kendaraannya sembarangan. Bahkan kadang menyerobot parkir khusus atau menggangu akses pejalan kaki untuk keluar/masuk suatu gedung.

\section{Zona Pengamatan 1 (Gedung Baru FST)}

Halaman gedung baru FST yang cukup luas sangat sesuai diperuntukan sebagai lapangan parkir bagi civitas akademika. Fasilitas pos keluar/masuk menandakan adanya minat pihak pengelola kampus untuk menjadikannya sebagai salah satu tempat parkir utama untuk mengatasi kebutuhan parkir. Kurangnya fasilitas parkir seperti rambu dan garis marka atau bangunan parkir yang memadai, membuat kondisi parkir cenderung semwraut dan tidak terkendali, sehingga sering menggangu akses pejalan kaki yang hendak menuju ke bangunan ini. Kondisi parkir akan terlihat lebih parah ketika terjadi genangan air di sebagian tempat yang membuat parkir menjadi acak-acakan. Kekurangan lainnya adalah sarana peneduh parkir dan keamaanan kendaraan yang menjadi alasan mengapa sebagian besar mahasiswa enggan untuk menggunakan lahan ini sebagai tempat parkir favoritnya. Untuk melihat kondisi parkir pada Zona Utara dan Selatan Gedung Baru FST, dapat dilihat pada Gambar 4 dan Gambar 5. 


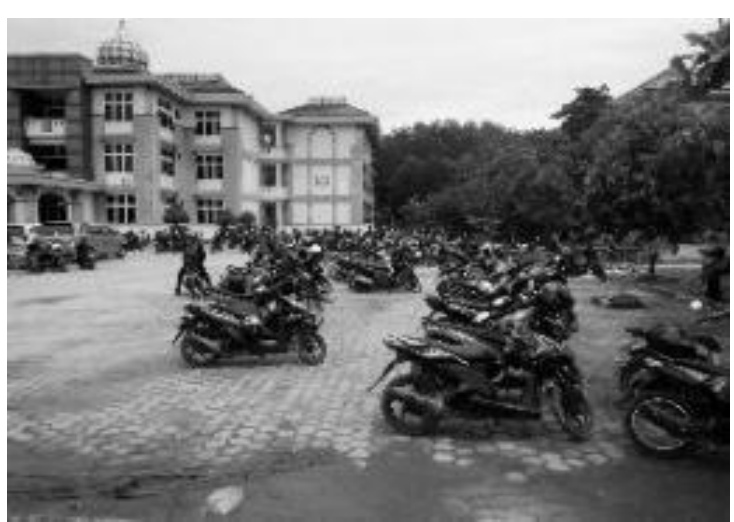

Gambar 4. Kondisi Parkir pada Zona Utara Gedung Baru FST

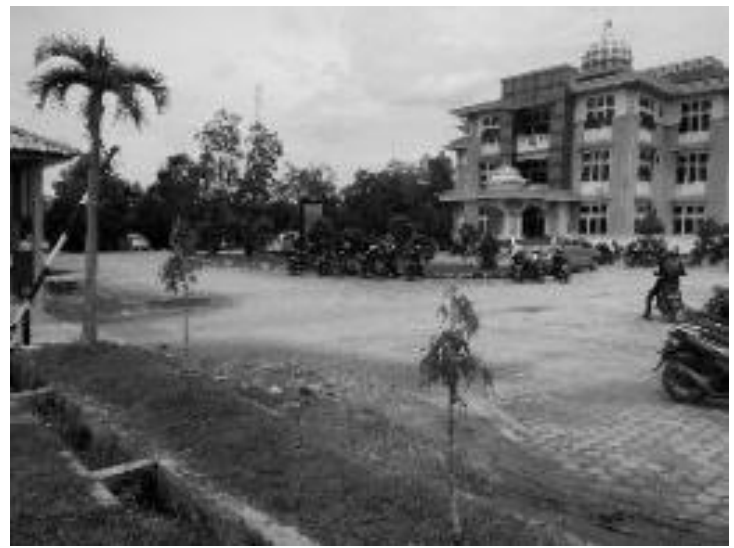

Gambar 5. Kondisi Parkir pada Zona Selatan Gedung baru FST

\section{Zona Pengamatan 2 (Area Gedung FST dan Lab)}

Halaman parkir sekitar gedung FST dan laboratorium telah dimanfaatkan sebagai lapangan parkir khusus pegawai dan dosen. Tetapi, penataan ruang parkir yang dominan di sini (aman dan teduh), membuat mahasiswa tertarik untuk berebut sebagai tempat favorit ruang parkir sebagian besar civitas akademika. Akibatnya, parkir menjadi membludak dan tidak terkendali serta menyebabkan para pegawai dan dosen sering kali harus mengalah ke tempat lain. Halaman depan dari FST ini dirancang untuk parkir kendaraan roda empat khusus untuk para tamu dan pimpinan fakultas. Sebagian lahan di antara FST dan Labouratorium juga diperuntukan untuk kendaraan roda empat bagi pegawai dan dosen. Permasalahan yang timbul ketika musim hujan, dimana lahan mulai becek dan banjir membuat parkir roda empat ini menjadi berantakan. Pengerasan dan pembangunan sarana peneduh kendaraan diperlukan untuk menjaga kerapian dan ketertiban di area parkir ini. Untuk melihat kondisi parkir pada zona pegawai, dapat dilihat pada Gambar 6. Sedangkan kondisi parkir pada zona Gedung Laboratorium FST dapat dilihat pada Gambar 7.



Gambar 6. Kondisi Parkir Pada Zona Pegawai

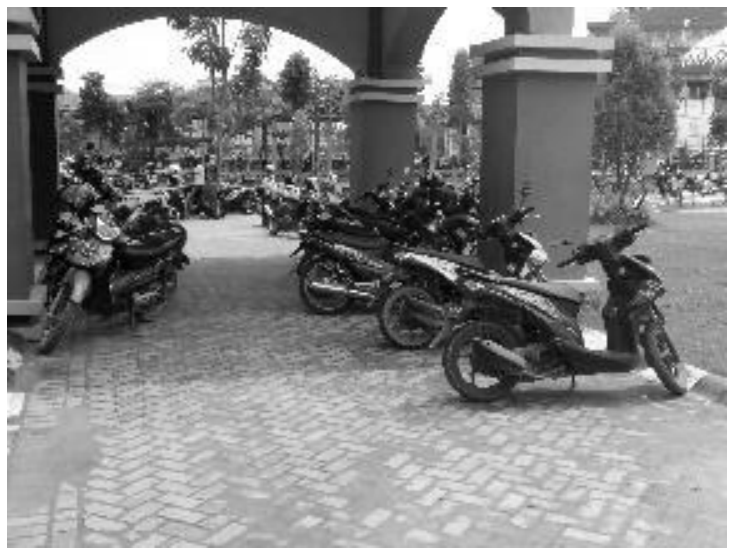

Gambar 7. Kondisi Parkir Pada Zona Gedung Laboratorium

\section{Zona Pengamatan 3 (Koridor Akses Keluar/ Masuk Mesjid)}

Penggunaan area ini sebagai tempat parkir kendaraan sangat mengganggu akses keluar /masuk para jama'ah masjid yang ingin melaksanakan ibadah sholat. Fenomena saling berdesak-desakan jamaah yang ingin keluar/masuk lingkungan masjid sering kali terjadi ketika pelaksanaan sholat dhuzur dan ashar. Terkadang, kondisi ini sering membuat laki-laki dan perempuan bersinggungan karena sempitnya ruang gerak yang tersisa akibat parkir yang umumnya disebabkan oleh mahasiswa FST.

Meskipun kondisi parkir di area ini tergolong tidak aman dari tindakan pencurian, tetapi mahasiswa terpaksa memilih untuk berspekulasi parkir pada area ini mengingat tempatnya yang teduh dan nyaman. Akibatnya, trotoar yang memsisahkan koridor dan jalanan menjadi hancur dan rusak akibat dilewati oleh banyak kendaraan. Hal ini harus segera diatasi dengan adanya pelarangan parkir di sekitar area ini untuk menjaga ketertiban ibadah di lingkungan Masjid UIN Suska Riau. Untuk melihat kondisi parkir yang ada pada koridor antara masjid dengan Gedung Islamic Center dapat dilihat pada Gambar 8 . 


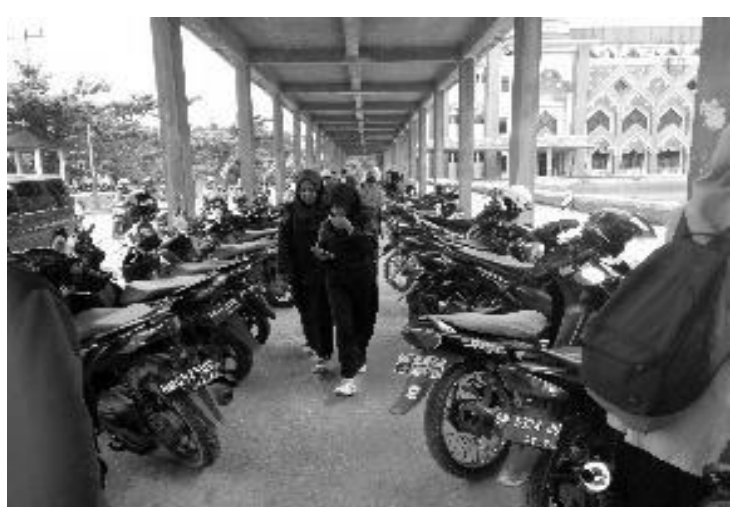

Gambar 8. Penggunaan Koridor Masjid - Islamic Center

\section{Zona Pengamatan 4 dan 5 (Ruang Terbuka Gedung Psikologi lama)}

Area ini merupakan tempat penampungan luapan parkir yang tidak terlayani oleh zona parkir yang lain. Kondisi ruang terbuka di area ini rawan terhadap hujan (becek) dan tindakan pencurian. Hal ini dikarenakan belum adanya perencanaan ruang parkir untuk wilayah ini. Areanya yang cukup luas, membuat kondisi parkir tidak dapat tertata dengan baik, sehingga akses pejalan kaki yang menuju ke arah ini (Gedung Psikologi lama) sangat terganggu. Dalam kondisi tertentu kadang parkir sepeda motor dan kendaraan roda empatpun saling berbaur, sehingga memberikan ketidaknyamanan dalam menggunakan ruang parkir di area ini.

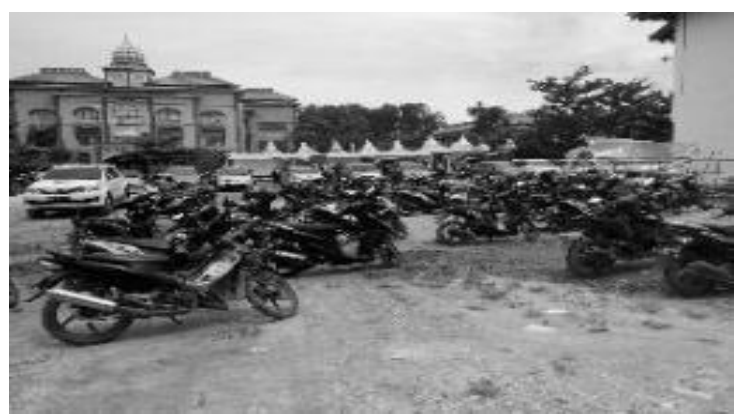

(a)

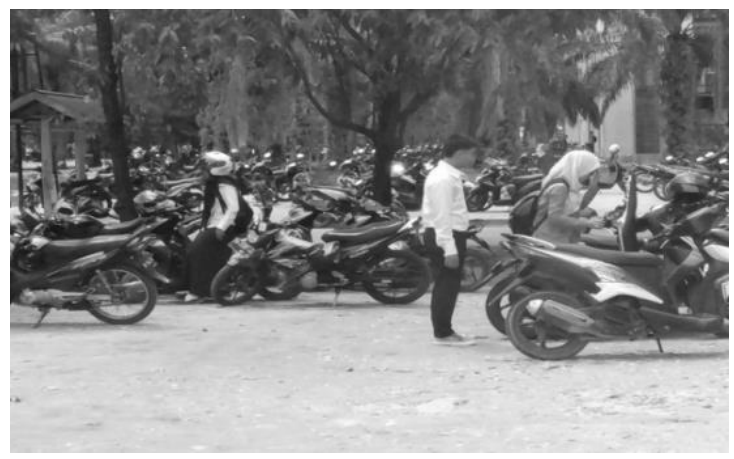

(b)

Gambar 9. Kondisi Parkir pada Ruang Terbuka di Sekitar Gedung Psikologi Lama
Mengingat tingginya permintaan parkir akhirakhir ini di lingkungan FST, keberadaan ruang terbuka ini harus diperhitungkan sebagai tempat parkir alternatif bagi mahasiswa FST dan Tarbiyah. Hal ini mengingat tempatnya memiliki akses strategis dan luas lahan yang cukup memadai untuk membangun tempat parkir yang lebih layak menampung luapan parkir dari Gedung Baru dan Gedung FST. Pembangunan sarana peneduh parkir dan pos-pos pengamatan satpam untuk menjaga keamaan parkir di area ini sangat diperlukan agar mahasiswa tertarik untuk memanfaatkannya sebagai ruang parkir favorit. Gambar 9 (a) dan (b) merupakan kondisi area parkir yang ada disekitar Gedung Psikologi Lama.

\section{Kebutuhan Ruang Parkir Kampus}

\section{Populasi Civitas Akademika}

Berdasarkan hasil diskusi pada FGD yang telah dilaksanakan, kedatangan civitas akademika (khususnya para mahasiswa) ke kampus memiliki alasan tersendiri dan bervariasi. Secara umum alasan tersebut menyangkut kegiatan perkuliahan dan pratikum yang harus dilaksanakan di kampus. Sehingga populasi perkuliahan khsususnya mahasiswa sangat bergantung pada jadwal perkuliahan dan jumlah mahasiswa yang mengikutinya. Namun, jadwal perkuliahan dan pratikum ini juga bergantung pada jumlah ruang dan kapasitas yang dapat menampung populasi tersebut. Artinya, populasi mahasiswa maksimum dapat diperkirakan sebagai daya tampung maksimum ruang-ruang kelas yang ada pada fakultas tersebut.

Hal inilah yang menjadi alasan, mengapa metode analisa menggunakan laju pertumbuhan mahasiswa dari tahun ke tahun menjadi tidak valid lagi karena dibatasi oleh daya tampung sarana dan prasarana kampus. Faktanya, laju pertumbuhan jumlah kelas dan labor belum tentu bertambah untuk setiap tahunnya. Hasil observasi ke ruang-ruang kelas yang dimiliki oleh FST dapat diperoleh data sebagaimana yang diperlihatkan pada Tabel 3 .

Tabel 3. Sarana Ruang Kelas Mahasiswa di FST

\begin{tabular}{|l|c|c|c|}
\hline \multicolumn{1}{|c|}{ Lokasi } & Ruang & Kapasitas & Jumlah \\
\hline Gedung FST & 17 ruang & 30 orang & 510 orang \\
\hline Gedung Baru & 7 ruang & 30 orang & 210 orang \\
\hline $\begin{array}{l}\text { Gedung } \\
\text { Psikologi }\end{array}$ & 10 ruang & 30 orang & 300 orang \\
\hline Labouratorium & 8 ruang & 10 orang & 240 orang \\
\hline \multicolumn{3}{|l|}{ Jumlah total kapasitas } & $\begin{array}{l}1.240 \\
\text { orang }\end{array}$ \\
\hline
\end{tabular}

Untuk perhitungan jumlah dosen pengampu matakuliah dapat diasumsikan sebagai jumlah ruang kelas yang tersedia yakni 42 orang dosen untuk 
waktu perkuliahan yang sama. Sehingga jumlah mahasiwa dan dosen yang terlibat dalam satu waktu perkuliahan adalah 1.282 orang. Tetapi pada saat perkuliahan berakhir dan perkuliahan berikutnya mulai dilaksanakan, jumlah populasi ini sangat memungkinkan untuk meluap karena mahasiswa yang mengikuti perkuliahan selanjutnya sangat memungkinkan berasal dari populasi yang berbeda. Meluapnya populasi ini disebabkan oleh mereka yang telah menyelesaikan perkuliahannya belum tentu langsung pulang meninggalkan kampus, dan mereka yang akan mengikuti perkuliahan jadwal selanjutnya, boleh jadi datang lebih awal dari jadwal yang telah ditetapkan.

Selain itu, luapan juga berasal dari mahasiswa yang datang ke kampus dengan tujuan lainnya. Seperti kebutuhan bimbingan dosen, pengerjaan tugas, seminar/sidang akhir dan lain sebagainya. Besarnya luapan ini sangat dipengaruhi juga oleh keberadaan ruang publik dan ruang terbuka lainnya yang diduduki oleh para mahasiswa selama berada di kampus FST. Jika luapan populasi ini diasumsikan $30 \%$ dari populasi di atas, maka jumlah populasi menjadi 1.666 .

Jumlah ini belum menunjukkan jumlah populasi total persatuan waktu perkuliahan. Kehadiran dosen, pimpinan, staf dan karyawan lainnya juga mempengaruhi populasi civitas akademika. Berdasarkan hasil observasi data absensi, rata-rata jumlah ini berkisar 60 orang perharinya. Sehingga populasi total civitas akademika maksimum yakni 1.726 orang yang merupakan gambaran terburuk yang dapat memengaruhi suasana parkir di lingkungan FST persatuan waktu. Hal ini sangat perlu diperhatikan oleh pihak pengelola kampus untuk sesegera mungkin membenahi fasilitas yang dimilikinya agar dapat melayani jumlah populasi yang besar.

\section{Populasi Civitas Akademika}

Populasi kendaraan yang keluar/masuk area parkir dapat dibangkitkan dari populasi civitas akademika pada waktu yang sama. Rasio kepemilikan kendaraan bermotor dikalangan civitas akademika merupakan porsi masing-masing jenis kendaraan yang membangkitkan akumulasi parkir pada saat itu. Data rasio kepemilikan ini dapat diperoleh dengan dua cara, yakni melakukan sensus dengan sampling waktu, atau dengan melakukan sampling observasi pada beberapa waktu yang berbeda. Metoda yang digunakan dapat berupa survey/pengamatan, atau dapat juga dengan melakukan penyebaran kuisoner. Berdasarkan hasil survei lapangan pada 5 hari berturut-turut, data kepemilikan jenis kendaraan yang digunakan oleh mahasiswa untuk mencapai kampus diperlihatkan oleh grafik pada Gambar 10.

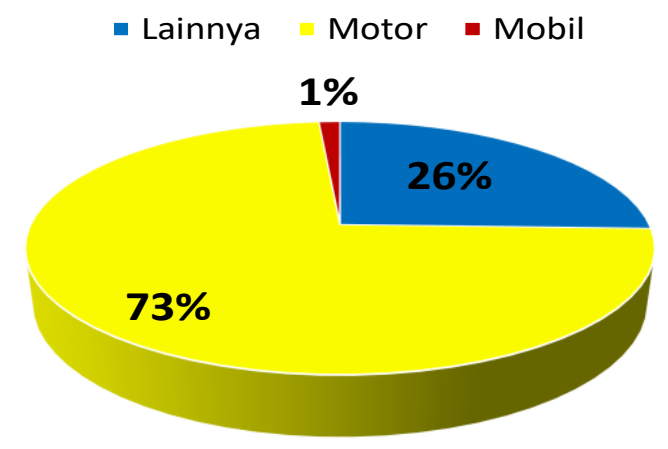

Gambar 10. Pola Pemilihan Kendaraan Bermotor di FST

Berdasarkan grafik pada Gambar 10, dapat disimpulkan bahwa $73 \%$ mahasiswa memilih sepeda motor, atau dengan kata lain terdapat populasi sebesar 1.260 kendaraan sepeda motor yang keluar/masuk area kampus dalam durasi waktu tertentu (dalam hal in adalah dalam satu jam pengamatan). Dari grafik Gambar 10 tersebut juga dapat disimpulkan hanya terdapat 18 kendaraan mobil yang membutuhkan parkir dalam waktu yang sama.

\section{Perhitungan dan Rancangan Layout Parkir}

\section{a. Ruang Terbuka Belakang Gedung Lama Psikologi}

Pada area ruang terbuka ini, petak parkir dapat dibangun pada halaman belakang Gedung Lama Psikologi sebagai parkir khusus sepeda motor bagi mahasiswa. Ukuran lahan parkir yang dipergunakan adalah $107.75 \mathrm{~m}$ x $13 \mathrm{~m}$ dengan dua gang pemisah antar petak parkir yakni 2 x 2 m untuk masing-masing baris. Untuk mendapatkan Total kapasitas parkir maksimum dipergunakan model petak parkir D, yakni dua baris parkir untuk setiap petaknya.

Hasil perhitungan kapasitas yang diperoleh adalah 4 petak $2 \times 50 \mathrm{SRP}+2$ petak $2 \times 37 \mathrm{SPR}=$ 548 SRP. Sedangkan sisi kanan dan kiri dari gedung dapat dimanfaatkan sebagai pos penjagaan dan taman atau ruang publik lainnya bagi mahasiswa. Untuk melihat layout parkir sepeda motor pada Gedung Lama Psikologi dapat dilihat pada Gambar 11. 


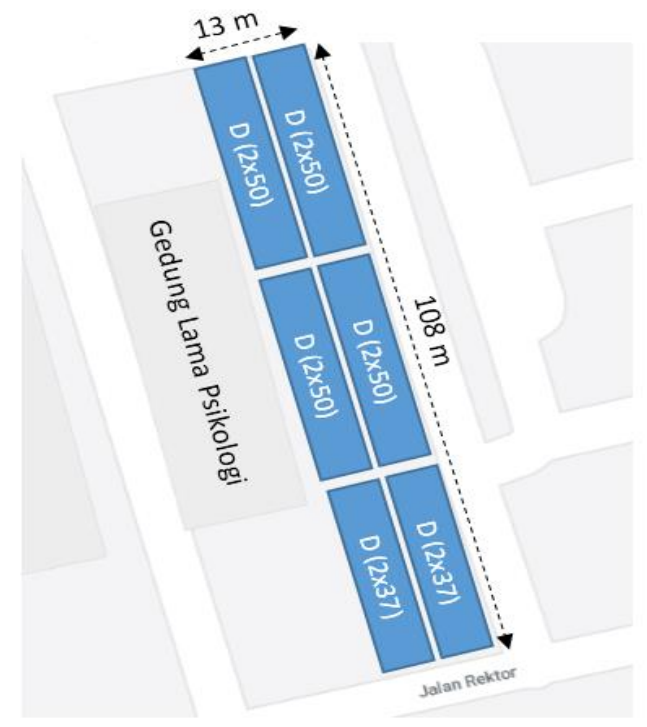

Gambar 11. Layout Parkir Sepeda Motor Gedung Lama Psikologi

\section{b. Halaman Parkir Gedung Baru}

Halaman gedung baru ini telah dilengkapi dengan pos penjagaan pada pintu masuk/keluar kendaraan. Kurangnya fasilitas peneduh kendaraan dan garis marka parkir membuat mahasiwa parkir dengan semena-mena dan berantakan. Halaman parkir ini dibatasi oleh parit pada sisi kiri dan depan gedung dan ditandai dengan batas garis pada pos penjagaan. Area yang didapat dimanfaatkan adalah sebagaimana yang diperlihatkan pada Gambar 12.

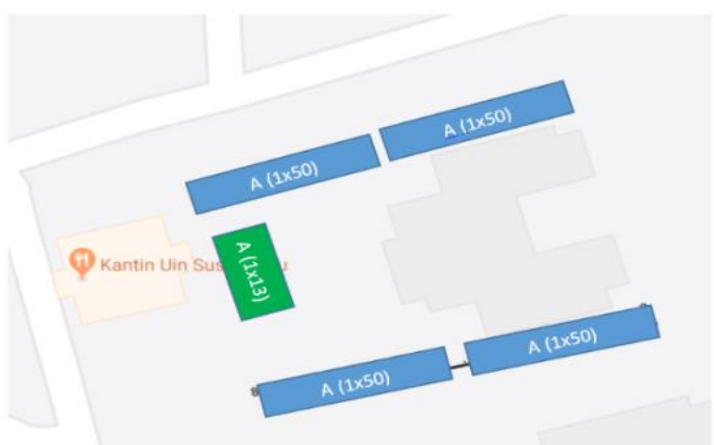

Gambar 12. Rancangan Layout Parkir Pada Gedung Baru FST

Layout parkir sepeda motor dan kendaraan roda empat dirancang dengan menggunakan model A, yakni 4 petak parkir 1 x $50=200$ SRP untuk sepeda motor dan 1 x $13=13$ SRP untuk kendaraan roda empat. Antara petak parkir sepeda motor dapat dipisahkan dengan gang maksimum 5 meter sebagai jalan akses dari gedung FST ke Gedung baru ini. Penggunaan sisa lahan lebih baik dipergunakan sebagai taman atau lapangan untuk kegiatan lainnya bagi mahasiswa.

\section{c. Halaman Parkir Gedung FST}

Fasilitas parkir pada halaman Gedung FST dan Laboratorium sebagian telah dibangun seperti petak parkir khusus pimpinan FST (warna merah), petak parkir kendaraan roda empat (warna hijau), dan petak parkir sepeda motor di sisi kiri gedung FST. Sedangkan petak parkir pada sisi kiri gedung Laboratorium belum terbangun. Sehingga kondisi parkir sering tidak rapi. Beberapa bagian belum difasilitasi oleh peneduh panas dan untuk parkir sepeda motor pada sisi kiri gedung FST belum terbangun maksimal. Adapun kapasitas parkir yang dapat diberikan dengan rancangan layout seperti Gambar 13 adalah 200 SRP untuk sepeda motor dan 29 SRP untuk kendaraan roda empat.

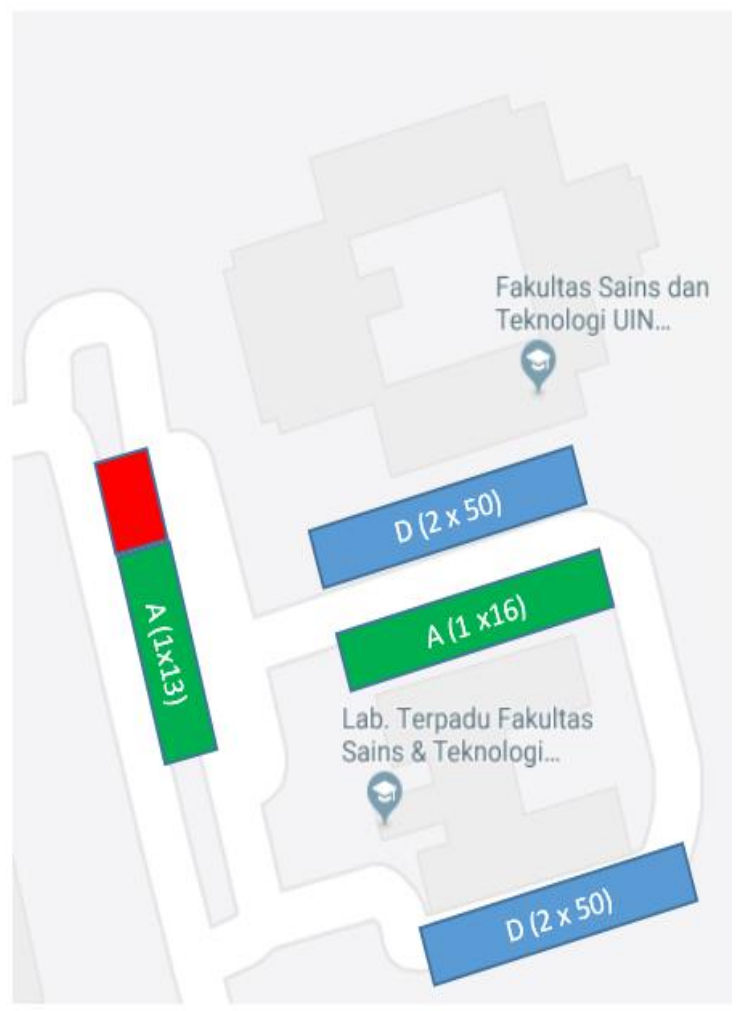

Gambar 13. Layout Parkir Gedung FST dan Labor

\section{Perhitungan dan Rancangan Layout Parkir}

Dari hasil pembahasan sebelumnya, kapasitas parkir dengan rancangan layout yang telah diberikan diperoleh kapasitas parkir untuk sepeda motor sebanyak 948 SRP, dimana 100 SRP diantaranya adalah khusus dosen dan pegawai. Sedangkan kapasitas parkir untuk kendaraan roda empat sebanyak 42 SRP. Hasil ini belum mencukupi kebutuhan SRP untuk populasi maksimum civitas akademika yakni sebesar 1.260 SRP untuk sepeda motor. Artinya dibutuhkan lahan parkir 312 SRP sepeda motor untuk mencapai kebutuhan maksimum. 
Hasil pantauan di lapangan diperoleh akumulasi parkir sepeda motor mencapai titik tertinggi pada jam pergantian perkuliahan 10:00 sampai dengan 11:00 WIB, yakni sebesar 1.133 SRP. Jika dijumlahkan dengan akumulasi parkir sepeda motor civitas akademika lainnya yakni 67 SRP (lihat Gambar 14 dan Gambar 15), maka telah terjadi kebutuhan parkir sepeda motor sebesar 1.200 SRP. Dengan kata lain, kapasitas parkir yang dapat diberikan dengan luas area terbuka di sekitar lingkungan FST tidak mencukupi dalam menampung kebutuhan parkir maksimum saat ini. Apalagi ketika populasi civitas akademika yang maksimum.
Solusi untuk permasalahan tersebut dapat dilakukan dengan dua cara, yakni dengan melakukan optimasi kapasitas untuk sisa-sisa ruang terbuka lainnya seperti pada Gedung Baru dan Gedung Lama Psikologi, dan dengan menekan laju penggunaan sepeda motor dikalangan mahasiswa berbasis kebijakan parkir atau perkuliahan. Untuk solusi pertama, keberadaan gedung parkir mungkin solusi terbaik untuk tetap mempertahankan nilai keindahan dan ketertiban lingkungan. Sedangkan kebijakan parkir dan sistem parkir yang terintegrasi diperlukan untuk mengetahui karakteristik parameter parkir lainnya agar dapat ditindak-lanjuti dengan alasan yang lebih memadai.

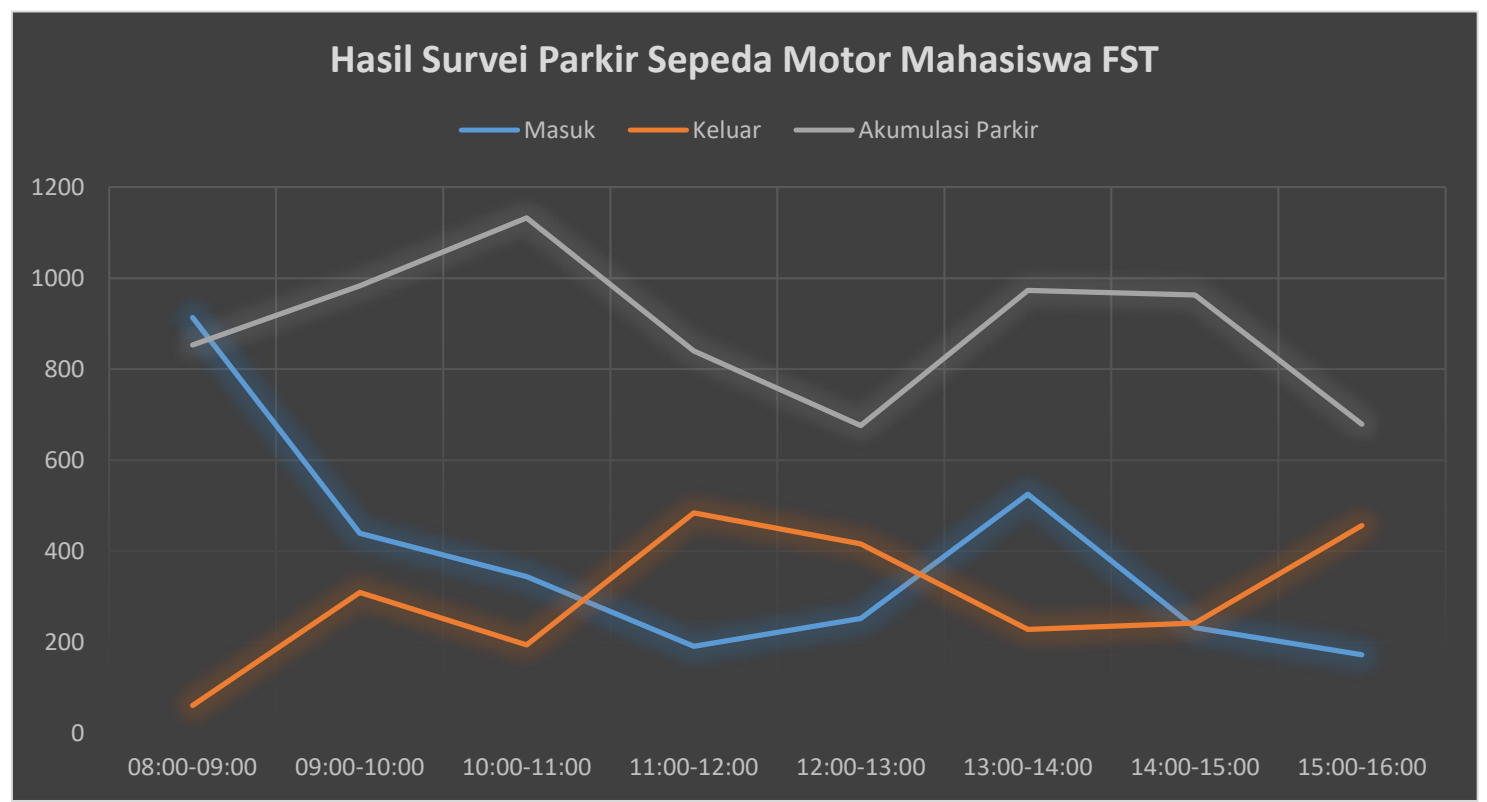

Gambar 14. Hasil Survei Keluar/Masuk Kendaraan Sepeda Motor Mahasiswa

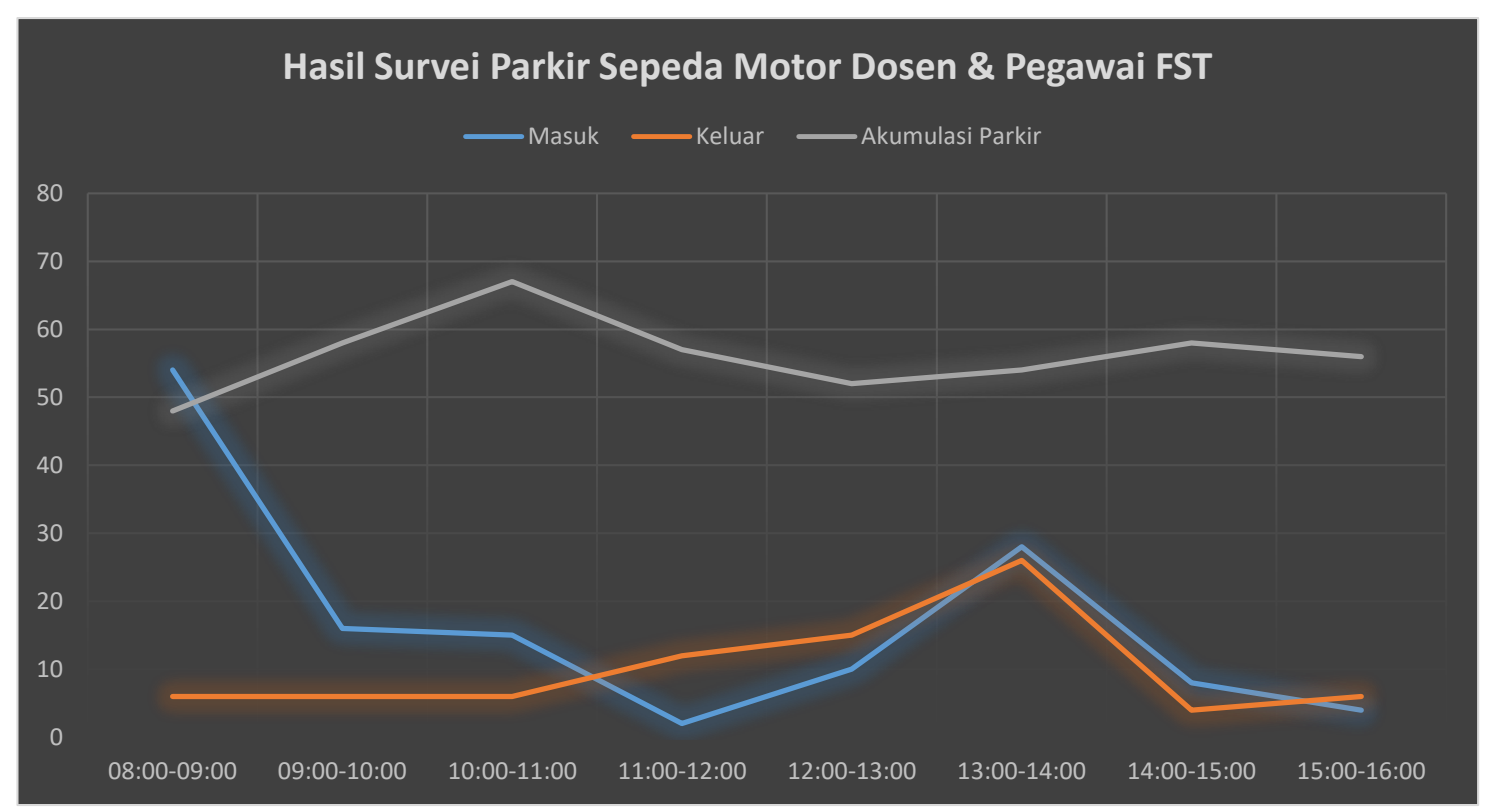

Gambar 15. Hasil Survei Keluar/Masuk Kendaraan Sepeda Motor Dosen dan Pegawai 


\section{Kesimpulan}

Kondisi parkir di lingkungan FST harus mendapatkan perhatian khusus dari pihak pengelola kampus untuk menghindari hal-hal yang merugikan dan tidak diinginkan oleh semua pihak. Pengadaan fasilitas parkir saat ini masih dirasakan minim dan perlu perencanaan pembangunan yang lebih matang, sehingga seluruh citivas akademika mendapatkan sarana parkir yang nyaman dan aman dari tindakan criminal lainnya. Berdasarkan fakta di lapangan saat ini, pihak pengelola kampus hanya menyediakan fasilitas parkir bagi pegawai dan dosen. Sedangkan fasilitas parkir untuk para mahasiswanya belum dibangun sama sekali, sehingga parkir liar terjadi di mana-mana.

Hasil penelitian menunjukkan bahwa kebutuhan parkir sepeda motor minimum membutuhkan 1200 SRP, dimana 948 SRP penggunaannya didominasi oleh mahasiswa. Pemanfaatan lahan area terbuka disekitar kampus hanya mampu menampung $75 \%$ dari total yang dibutuhkan oleh sepeda motor. Sedangkan kebutuhan parkir kendaraan roda empat dibutuhkan lahan sebesar 42 SRP, di mana kekurangan dari daya tampung fasilitas yang ada dapat diatasi dengan menggunakan lahan area terbuka yang ada. Dengan kata lain, penelitian merekomendasikan untuk membangun gedung parkir untuk mengakomodir sisa kebutuhan SRP parkir khususnya untuk sepeda motor. Pilihan solusi lainnya adalah dengan memanfaatkan kebijakan penggunaan kendaraan dalam kampus untuk menekan jumlah SRP yang diperlukan pada jam-jam sibuk.

\section{Ucapan Terima Kasih}

Kami mengucapkan terima kasih kepada LPPM yang telah membiayai penelitian ini hingga selesai dan Tim Peneliti Sistem Informasi Sistem Informasi Organisasi Sistem Informasi (ISOC) Universitas Islam Negeri Sultan Syarif Kasim Riau, Riau yang telah membantu kelancaran penelitian ini.

\section{Daftar Pustaka}

[1] Abdelfatah, A. S., \& Taha, M. A. (2014). Parking capacity optimization using linear programming. Journal of traffic and logistics engineering, 2(3).

[2] Alamsyah, W., \& Purwandito, M. (2015). Studi Ruang Parkir Universitas Samudra Kampus Meurandeh. Jurutera, 2(01), 11-18..

[3] Primasari, D. W., Ernawati, J., \& Wicaksono, A. D. (2013). Pemilihan moda transportasi ke kampus oleh mahasiswa Universitas Brawijaya. The Indonesian Green Technology Journal, 2(2), 84-93.

[4] Tarigan, E., \& Ariani, D. W. (2014). Evaluasi Tata Letak (Layout) dan Kapasitas Parkir Kendaraan Sepeda Motor di Universitas Atma Jaya Yogyakarta Kampus III Gedung Bonaventura. Skripsi Jurusan Manajemen, Fakultas Ekonomi Universitas Atma Jaya Yogyakarta.

[5] Widhiastuti, R., \& Priyadi, E. (2013). Evaluasi Dan Analisis Kebutuhan Ruang Parkir Di Kampus Politeknik Negeri Pontianak. Jurnal Teknik Sipil, 13(1).

[6] Anonymous, Pedoman Perencanaan dan Pengoperasian Fasilitas Parkir, Direktorat Bina Sistem Lalu Lintas dan Angkutan KotaDirjen Perhubungan Darat, Jakarta.

[7] Montgomery, D. C., Runger, G. C., \& Hubele, N. F. (2009). Engineering statistics. John Wiley \& Sons..

[8] Harsono, A. (2008). Metode Analisis Akar Masalah dan Solusi. Makara, Sosial Humaniora, 12(2), 72-81..

[9] Anonymous. (2008). Mastering Online Discussion Board Facilitation-Resource Guide. TeacherStream, LLC.

[10] Paramita, A., \& Kristiana, L. (2013). Teknik Focus Group Discussion Dalam Penelitian Kualitatif. Buletin Penelitian Sistem Kesehatan, 16(2), 20840..

[11] DeLancey, C. (2018). A Concise Introduction to Logic. 